\title{
Analisis Kualitas Pelayanan dan Fasilitas Day-Spa di Medan
}

\author{
Shafira Ayu Syukrani1, M. Rezki Setiawan'1, Ferdiana Shinta Triliasa1, Dandi \\ Nostiagi Rosta1, Imam Fauzan Syahputra1, Indra Kesuma Hadi², Muhammad Amin ${ }^{2}$ \\ ${ }^{1}$ Mahasiswa Jurusan Teknik Arsitektur, Institut Teknologi Medan \\ 2 Dosen Jurusan Teknik Arsitektur, Institut Teknologi Medan \\ ferdiana.shinta2015@gmail.com
}

\begin{abstract}
ABSTRAK
Tujuan penelitian ini adalah untuk mengetahui pemenuhan kualitas pelayanan dan fasilitas day-spa yang sesuai dengan kebutuhan pengguna, khususnya Ubud Family Reflexology, De Spa dan Zengarden di Medan. Di Kota Medan, day-spa banyak berlokasi di dekat pusat perbelanjaan, permukiman elite, perkantoran, dan kawasan komersial, serta banyak dikonsumsi oleh kalangan eksekutif perkantoran, ibu-ibu sosialita, mahasiswi, serta bayi dan balita. Dalam merancang bangunan spa perlu memperhatikan dan mempertimbangkan psikologis pengguna, khususnya konsumen, maka perlu diketahui bahwa fasilitas serta tingkat privasi ruangan berdampak pada perilaku konsumen. Metode penelitian dengan wawancara, observasi, dan analisis studi dokumen. Hasil dari penelitian ini menunjukkan bahwa bangunan day-spa di Medan belum menggunakan standar fasilitas dan pelayanan spa.
\end{abstract}

Kata Kunci: spa, solus per aqua, kualitas, pelayanan, fasilitas

ABSTRACT

The purpose of this study is to find out the quality of services and Day-Spa facilities that correspond to user needs, especially Ubud Family Reflexology, De Spa, and Zengarden in Medan. In Medan City, day-spas are located are many located near shopping malls, elite settlements, office complex, and commercial areas. They are widely consumed by office executives, socialite mothers, college students, babies, and toddlers. In designing a spa building, it needs to observe and consider psychological users, especially consumers, it should be noted that facilities and privacy levels in the room are affecting consumer behavior. The research methods use interviewing, observing, and analyzing the document study. The results from this study indicate that day-spa buildings in Medan do not apply standard facilities and spa services.

Keywords: spa, solus per aqua, quality, service, facilities

\section{Pendahuluan}

Permenkes (2004) menjelaskan bahwa spa adalah suatu upaya kesehatan tradisional dengan pendekatan holistik, berupa perawatan menyeluruh menggunakan kombinasi keterampilan hidroterapi, pijat, aromaterapi, dan di tambahkan pelayanan makanan, minuman sehat serta olah aktivitas fisik. Di Sumatera Utara sendiri, khususnya Medan, day-spa banyak berlokasi di dekat pusat perbelanjaan, permukiman elite, perkantoran, dan kawasan komersial. Day-spa di Medan banyak dikonsumsi oleh kalangan eksekutif perkantoran, ibu-ibu sosialita, mahasiswi, serta bayi dan balita. Survei (2019) yang dilakukan menunjukkan bahwa beberapa bangunan day-spa di Medan memiliki pelayanan yang minim, penggunaan ruang yang bersifat multi-fungsi. 
Kebijakan tersebut dapat mengurangi tingkat privasi konsumen, dan berpengaruh pada pencapaian yang cukup lama dalam meningkatkan relaksasi tubuh dan pikiran konsumen day-spa, sehingga menurunnya kualitas kepuasan konsumen.

Dari beberapa masalah di atas, dapat disimpulkan bahwa fasilitas serta tingkat privasi ruangan berdampak pada keberlangsungan kegiatan yang terjadi di bangunan day-spa, serta menurunnya kualitas day-spa. Maka dalam merancang bangunan day-spa perlu memperhatikan dan mempertimbangkan standar-standar yang ada, serta pemenuhan pelayanan dan fasilitas yang berkualitas. Oleh karena itu, penulis melakukan penelitian dengan judul "Analisis Kualitas Pelayanan dan Fasilitas day-spa di Medan”, khususnya Ubud Family Reflexology, De Spa, dan Zengarden.

\section{Bahan dan Metode}

Penelitian ini menggunakan data berupa teori-teori dan studi jurnal yang berkaitan dengan spa. Data-data dibawah merupakan pedoman peneliti dalam meneliti secara langsung maupun dalam pengolahan data hasil survei.

\subsection{Standar Perancangan Day-Spa}

Menurut Peraturan Menteri Pariwisata dan Ekonomi Kreatif Republik Indonesia Nomor 24 Tahun 2014 Tentang Standar Usaha spa, kategori Spa Tirta 1, terdapat beberapa fasilitas dan pelayanan seperti terlihat pada Tabel 1.

\section{Tabel 1. Standar Usaha Spa Kategori Tirta 1}

\begin{tabular}{|c|c|}
\hline Fasilitas & Pelayanan \\
\hline $\begin{array}{l}\text { - Ruang perawatan Terapi Pijat, rempah dan } \\
\text { wajah; } \\
\text { - Ruang perawatan pijat kaki dan tangan; } \\
\text { - Ruang perawatan lulur dan masker; } \\
\text { - Ruang perawatan terapi air meliputi ruang } \\
\text { berendam dan mandi uap; } \\
\text { - Area penerima penerimaan tamu; } \\
\text { - Ruang loker tamu dan karyawan terpisah; } \\
\text { - Toilet yang bersih serta terpisah untuk pria dan } \\
\text { wanita; } \\
\text { - Area bilas; } \\
\text { - Area minum; } \\
\text { - Ruang kantor; } \\
\text { - Ruang linen; } \\
\text { - Toilet yang bersih untuk karyawan dan pengelola } \\
\text { terpisah; } \\
\text { - Ruang Pertolongan Pertama Pada Kecelakaan } \\
\text { (P3K) dan Alat Pemadam Api Ringan (APAR); } \\
\text { - Gudang. }\end{array}$ & $\begin{array}{l}\text { a. Pelayanan tamu } \\
\text { - Penyambutan kedatangan tamu; } \\
\text { - Pendaftaran tamu; } \\
\text { - Pemberian informasi tentang produk dan } \\
\text { layanan spa; } \\
\text { - Pemberian konsultasi perawatan spa. } \\
\text { b. Pelayanan selama perawatan spa } \\
\text { - Terapi air; } \\
\text { - Terapi aroma; } \\
\text { - Terapi pijat; } \\
\text { - Terapi rempah; } \\
\text { - Terapi kaki dan tangan. } \\
\text { c. Pelayanan pasca perawatan spa } \\
\text { - Konfirmasi perawatan yang telah diberikan; } \\
\text { - Pemberian saran untuk perawatan di rumah; } \\
\text { - Pemberian saran untuk perawatan lanjutan. } \\
\text { d. Pelayanan minuman ringan yang sehat; } \\
\text { e. Pembayaran tunai dan non-tunai; } \\
\text { f. Pertologan Pertama Pada Kecelakaan (P3K); } \\
\text { g. Penanganan keluhan tamu; } \\
\text { h. Pelayanan keluar masuk kendaraan ke spa serta } \\
\quad \text { parkir. }\end{array}$ \\
\hline
\end{tabular}

(Sumber : Permenparekraf RI No. 24 tahun 2014)

Berdasarkan buku Time-Saver Standards for Architectural Design dan Neufert Architecs' Data Second Edition, standar perancangan spa dapat dilihat pada Tabel 2 berikut ini. 
Tabel 2. Standar Perancangan Spa

\begin{tabular}{|c|c|c|c|c|c|c|}
\hline No & Pengguna & Aktivitas & Kode & Kebutuhan Ruang & $\begin{array}{l}\text { Besaran } \\
\text { Ruang }\end{array}$ & Kapasitas \\
\hline \multirow{2}{*}{1} & \multirow{2}{*}{ Pimpinan } & Monitoring Pegawai & \multirow{5}{*}{$\begin{array}{l}\text { Kegiatan } \\
\text { Pendukung }\end{array}$} & Ruang Pimpinan & $28 m^{2}$ & $2-3$ \\
\hline & & Memimpin Rapat & & Ruang Rapat & $45 m^{2}$ & 20 \\
\hline \multirow{2}{*}{2} & \multirow{2}{*}{ Sekretaris } & Mengetik Laporan & & Ruang Sekretaris & $16 m^{2}$ & $2-3$ \\
\hline & & Menyimpan Dokumen & & Ruang Arsip & $6 m^{2}$ & 2 \\
\hline \multirow{11}{*}{3} & \multirow{11}{*}{ Pegawai } & Istirahat & & Ruang Pegawai & $16 m^{2}$ & $2-3$ \\
\hline & & Menerima Tamu & Kegiatan & Ruang Resepsionis & $28 m^{2}$ & $4-5$ \\
\hline & & Mengelola Pembayaran & Utama & Ruang Kasir & $16 m^{2}$ & $2-3$ \\
\hline & & Mencuci Kain & \multirow{8}{*}{$\begin{array}{l}\text { Kegiatan } \\
\text { Servis }\end{array}$} & Ruang Cuci & $12 m^{2}$ & $2-3$ \\
\hline & & Menyimpan Kain & & RuangPenyimpanan & $6 m^{2}$ & $2-3$ \\
\hline & & Istirahat & & Ruang Cleaning Sevice & $28 m^{2}$ & $4-5$ \\
\hline & & $\begin{array}{l}\text { Menyimpan Alat-alat } \\
\text { Kebersihan }\end{array}$ & & Gudang Alat & $6 m^{2}$ & $2-3$ \\
\hline & & & & Ruang Genset & $12 w^{2}$ & - \\
\hline & & Pemeliharaan & & Ruang MEE & $6 m^{2}$ & 2 \\
\hline & & & & Toilet Pegawai Pria & $3 m^{2}$ & 1 \\
\hline & & Buang Air & & Toilet Pegawai Wanita & $3 m^{2}$ & 1 \\
\hline \multirow{2}{*}{4} & \multirow{2}{*}{ Terapis } & Memijat Pelanggan & $\begin{array}{l}\text { Kegiatan } \\
\text { Utama }\end{array}$ & Ruang Terapi & $18 m^{2}$ & $10-15$ \\
\hline & & Istirahat & $\begin{array}{c}\text { Kegiatan } \\
\text { Servis }\end{array}$ & Pantry & $1,5 \mathrm{~m}^{2}$ & 5 \\
\hline \multirow{9}{*}{5} & \multirow{9}{*}{$\begin{array}{l}\text { Pekerjaan } \\
\text { Kantoran }\end{array}$} & & \multirow{13}{*}{$\begin{array}{c}\text { Kegiatan } \\
\text { Utama }\end{array}$} & Ruang Relaksasi & $5,25 \mathrm{~m}^{2}$ & 2 \\
\hline & & Melakukan Relaksasi & & Ruang Sauna Pria & $28 m^{2}$ & $4-5$ \\
\hline & & & & Ruang Sauna Wanita & $28 m^{2}$ & $4-5$ \\
\hline & & & & Whirlpool Pria & $16 m^{2}$ & $4-5$ \\
\hline & & Perawatan & & Whirlpool Wanita & $16 m^{2}$ & $4-5$ \\
\hline & & & & Ruang Bilas Pria & $3 m^{2}$ & 1 \\
\hline & & Membersihkan Dirı & & Ruang Bilas Wanita & $3 m^{2}$ & 1 \\
\hline & & Mengganti Pakaian dan & & Ruang Ganti dan Loker Pria & $5 m^{2}$ & 1 \\
\hline & & Menyimpan Barang & & Ruang Ganti dan Loker Wanita & $5 m^{2}$ & 1 \\
\hline 6 & $\begin{array}{l}\text { Pasangan } \\
\text { Suami-Istri }\end{array}$ & Perawatan & & Ruang Perawatan Couple & $20 m^{2}$ & 2 \\
\hline \multirow{3}{*}{7} & \multirow{3}{*}{$\begin{array}{l}\text { Ibu-Ibu } \\
\text { Sosialita }\end{array}$} & Berkonsultasi & & Ruang Konsultasi $S p a$ & $16 m^{2}$ & $2-3$ \\
\hline & & Perawatan & & Ruang Manicure dan Pedicure & $5,25 \mathrm{~m}^{2}$ & 2 \\
\hline & & Menunggu Antrian & & Ruang Tunggu & $45 m^{2}$ & 15 \\
\hline \multirow{3}{*}{8} & \multirow{3}{*}{ Mahasiswa } & Menunggu Antrian & \multirow{3}{*}{$\begin{array}{l}\text { Kegiatan } \\
\text { Servis }\end{array}$} & Lobby & $60 m^{2}$ & 50 \\
\hline & & Perawatan & & Ruang Perawatan Pria & $12 m^{2}$ & $1-3$ \\
\hline & & Buang Air & & Toilet Umum Pria & $3 m^{2}$ & 1 \\
\hline \multirow{4}{*}{9} & \multirow{4}{*}{ Mahasiswi } & Perawatan & $\begin{array}{l}\text { Kegiatan } \\
\text { Utama }\end{array}$ & Ruang Perawatan Wanita & $12 m^{2}$ & $1-3$ \\
\hline & & Ibadah & Kegiatan & Musholla & $20 m^{2}$ & 10 \\
\hline & & Refreshing & Pendukung & Coffee Corner & $36 m^{2}$ & 10 \\
\hline & & Buang Air & \multirow{3}{*}{$\begin{array}{l}\text { Kegiatan } \\
\text { Servis }\end{array}$} & Toilet Umum Wanita & $3 m^{2}$ & 1 \\
\hline \multirow{2}{*}{10} & \multirow{2}{*}{ Satpam } & Menjaga Keamanan & & Pos Satpam & $20 m^{2}$ & $3-4$ \\
\hline & & Buang Air & & Toilet & $3 m^{2}$ & 1 \\
\hline
\end{tabular}

(Sumber : konstruksi penulis, berdasar Neufert Architects' Data)

Setelah membuat rumusan standar perancangan spa, maka selanjutnya adalah menentukan studi jurnal tentang penelitian yang mirip dengan penelitian yang akan dilakukan. Studi jurnal akan dibahas adalah sebagai berikut.

\subsection{Studi Jurnal}

Jurnal yang dikutip adalah penelitian yang mirip dengan penelitian ini, namun terdapat beberapa perbedaan dalam penelitian-penelitian tersebut. Penelitian yang dikutip berupa Hubungan Warna Dengan Tingkat Stres Pengunjung (Zein dkk, 2013), 
Persepsi Masyarakat Surabaya Terhadap Spa Sebagai Sarana Perawatan Kesehatan, Kebugaran, dan Kecantikan (Pasla dan Dinata, 2004), dan Strategi Pengembangan Health And Wellness di Bali (Pramono, 2013). Dari ketiga jurnal di atas, dicapailah kesimpulan hasil penelitian dalam Tabel 3 berikut.

\section{Tabel 3. Kesimpulan Hasil Penelitian Jurnal}

\begin{tabular}{lll}
\hline \multicolumn{2}{c}{ Judul Penelitian } & \multicolumn{1}{c}{ Kesimpulan Hasil Penelitian } \\
\hline $\begin{array}{l}\text { Hubungan Warna Dengan Tingkat Stres } \\
\text { Pengunjung (Zein dkk, 2013) }\end{array}$ & $\begin{array}{l}\text { Diharapkan warna-warna yang sesuai akan dapat } \\
\text { digunakan untuk mengurangi dampak stress setelah } \\
\text { melakukan sejumlah spa treatment di ruangan tersebut. }\end{array}$ \\
\hline $\begin{array}{l}\text { Persepsi Masyarakat Surabaya Terhadap } \\
\begin{array}{l}\text { Spa Sebagai Sarana Perawatan Kesehatan, } \\
\text { Kebugaran, dan Kecantikan (Pasla dan } \\
\text { Dinata, 2004) }\end{array}\end{array}$ & $\begin{array}{l}\text { Berdasarkan hasil analisa data dengan One Sample Sign } \\
\text { Test, dimana hasilnya menerima H0', maka secara } \\
\text { signifikan H 0" diterima, yang berarti dugaan bahwa } \\
\text { image/citra SPA di Surabaya adalah buruk, tidak terbukti. }\end{array}$ \\
$\begin{array}{l}\text { Strategi Pengembangan Health } \\
\text { Wellness di Bali (Pramono, 2013) }\end{array}$ & $\begin{array}{l}\text { Besarnya peluang health and wellness Bali pada industri } \\
\text { wisata, sehingga diperlukannya penanganan pada strategi } \\
\text { pengembangan bidang wisata ini }\end{array}$ \\
\hline
\end{tabular}

(Sumber : konstruksi penulis berdasarkan Zein dkk. (2013), Pasla dan Dinata (2004), dan Pramono, (2013))

Berdasarkan hasil dari tiga penelitian di atas dapat disimpulkan bahwa penelitian yang akan dilakukan berbeda dari penelitian-penelitian sebelumnya dimana penelitian ini fokus pada kualitas pelayanan dan fasilitas pada bangunan day-spa terhadap perilaku pengguna. Setelah membahas studi jurnal tentang penelitian yang mirip dengan penelitian yang akan dilakukan, maka selanjutnya adalah pembahasan studi preseden.

\subsection{Studi Preseden}

Studi preseden yang dikutip adalah mirip dengan focus penelitian dilakukan dengan nama bangunan sebagai berikut: Hedon Spa, Estonia; Strom Spa Nordique, Canada; dan Naman Retreat Pure Spa, Vietnam. Dari ketiga preseden tersebut, didapatkan hasil seperti terlihat pada Tabel 4.

Tabel 4. Resume Studi Preseden

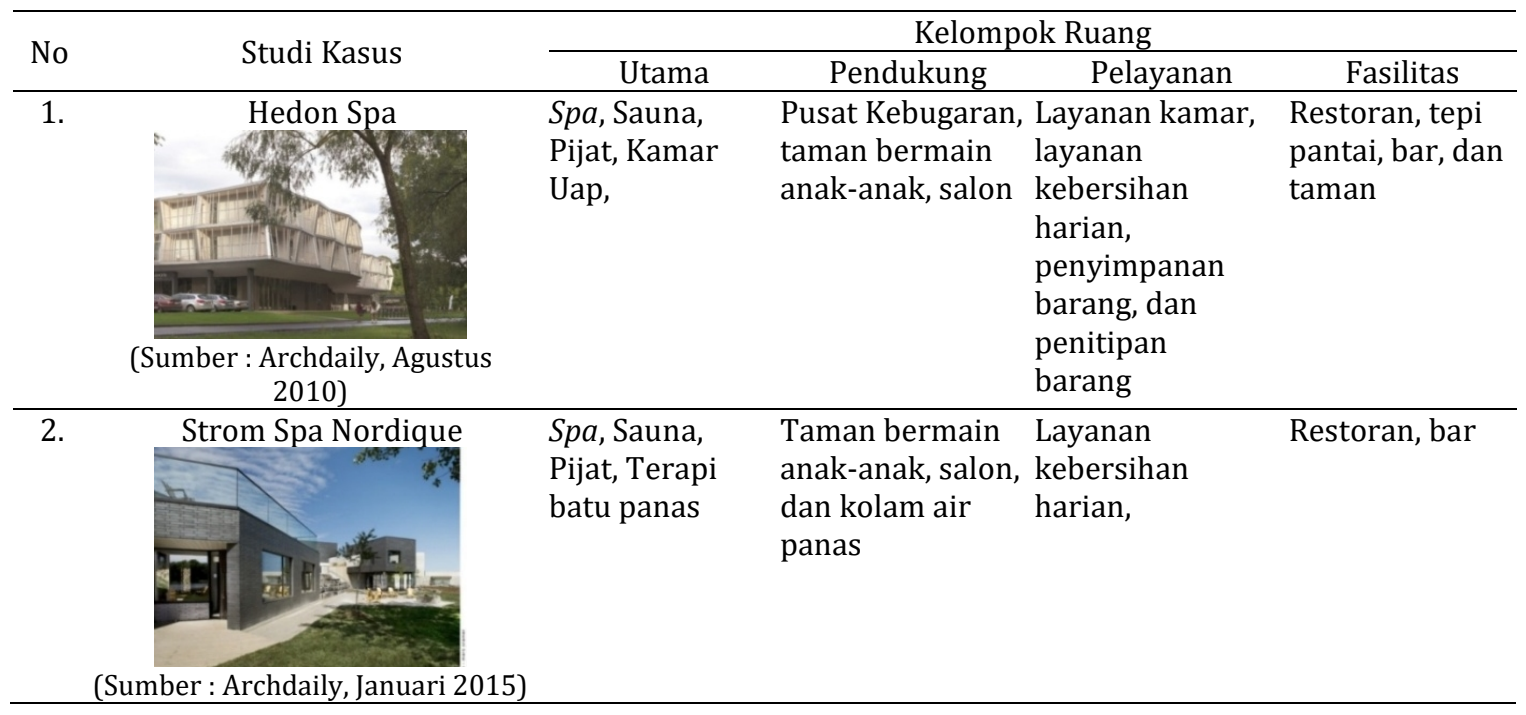




\begin{tabular}{|c|c|c|c|c|c|}
\hline 3. & Naman Retreat Pure Spa & $\begin{array}{l}\text { Spa, Sauna, } \\
\text { Pijat, Kamar } \\
\text { Uap, kolam } \\
\text { renang }\end{array}$ & $\begin{array}{l}\text { Pusat Kebugaran, } \\
\text { taman bermain } \\
\text { anak-anak, salon, } \\
\text { kolam air panas, } \\
\text { pantai pribadi, } \\
\text { memancing }\end{array}$ & $\begin{array}{l}\text { Layanan kamar, } \\
\text { layanan } \\
\text { kebersihan } \\
\text { harian, } \\
\text { penyimpanan } \\
\text { barang, } \\
\text { penitipan } \\
\text { barang, layanan } \\
\text { penitipan anak, } \\
\text { ruang CCTV }\end{array}$ & $\begin{array}{l}\text { Perpustakaan, } \\
\text { restoran, bar, } \\
\text { taman, toko } \\
\text { souvenir, dan } \\
\text { lapangan golf }\end{array}$ \\
\hline
\end{tabular}

Berdasarkan Tabel 4 dapat disimpulkan bahwa pelayanan dari ketiga spa tersebut sangat lengkap dengan standar fasilitas di atas rata-rata standar dan konsep yang digunakan ketiga spa tersebut adalah modern and nature.

\subsection{Kerangka Teoritik}

Dari ketiga bangunan yang telah diteliti, terdapat dua komponen yang mempengaruhi kualitas sebuah day-spa, antara lain sebagai berikut :

1. Fasilitas

Kebutuhan ruang mempengaruhi perilaku pengguna; meliputi standar ukuran, jumlah ruang sesuai dengan pelayanan, kegiatan pengguna, serta perabot yang digunakan.

2. Pelayanan

Pelayanan yang mempengaruhi perilaku pengguna meliputi penerimaan, konsultasi pra-perawatan, perawatan, konsultasi pasca-perawatan, dan keamanan.

\subsection{Metode Penelitian}

Penelitian ini merupakan penelitian kualitatif dengan menggunakan metode survei lapangan untuk mengumpulkan data dengan sampel purposif (bertujuan). Acuan penelitian terhadap fasilitas yang digunakan yaitu Standar Perancangan Spa berdasar Neufert Architects' Data. Pengumpulan data juga menggunakan teknik wawancara sebagai acuan penilaian terhadap pelayanan, yang diberikan kepada $30 \%$ dari keseluruhan konsumen day-spa secara acak di setiap lokasi penelitian, dengan indikator pertanyaan berdasarkan Zulian Yamit (2005) dan menggunakan skala rating (1-5) yang terdapat pada Tabel 5.

Tabel 5. Resume Studi Preseden

\begin{tabular}{|c|c|c|c|}
\hline Variabel & Sub Variabel & Indikator & $\begin{array}{c}\text { Jumlah } \\
\text { Pertanyaan }\end{array}$ \\
\hline \multirow{8}{*}{$\begin{array}{l}\text { Kualitas } \\
\text { pelayanan } \\
\text { day-spa }\end{array}$} & \multirow{3}{*}{ 1. Bukti langsung } & a. Fasilitas fisik & 1 \\
\hline & & b. Perlengkapan & 1 \\
\hline & & c. Sarana komunikasi & 1 \\
\hline & 2. Keandalan & Penyampaian jasa tepat waktu dan sesuai & 1 \\
\hline & 3. Daya tanggap & $\begin{array}{l}\text { Respond dan kesigapan karyawan serta } \\
\text { keluangan waktu pelayanan }\end{array}$ & 1 \\
\hline & 4. Jaminan & Jaminan keamanan dan keselamatan & 1 \\
\hline & \multirow{2}{*}{ 5. Empati } & a. Perhatian perusahaan kepada konsumen & 1 \\
\hline & & b. Kemudahan dalam melakukan komunikasi & 1 \\
\hline & & Total & 8 \\
\hline
\end{tabular}

(Sumber : konstruksi penulis berdasarkan Zulian Yamit, 2005) 
Berdasarkan Tabel 5 dengan rating antara 1-5, skor minimal yang diperoleh dari wawancara setiap responden yaitu 8 poin dan skor maksimal 40 poin. Metode analisis kualitatif yang dilakukan menggunakan teori-teori yang relevan dengan penelitian dan temuan-temuan di lapangan. Metode sintesis (kesimpulan) penelitian diperoleh melalui temuan-temuan di lapangan dengan teori-teori yang relevan. Lokasi penelitian yang dilakukan adalah spa yang secara administratif berada di Kelurahan Petisah Tengah, Petisah Hulu, dan Pandau Hilir, Kecamatan Medan Petisah dan Medan Perjuangan, Kota Medan. Ada tiga lokasi penelitian yang menjadi lokus amatan yaitu Ubud Family Reflexology, Zengarden, dan De Spa.

Saat ini terdapat sekitar 108 spa, sedangkan kategori day- spa di Medan hanya sekitar 14 day- spa dari keseluruhan spa yang ada. Dari 14 day- spa tersebut hanya ada 3 day- spa yang dapat dijadikan sampel penelitian dengan pertimbangan sebagai berikut:

a. Objek penelitian merupakan golongan Spa Tirta 1.

b. Objek penelitian dengan jumlah pelayanan terbanyak dan memiliki jumlah yang sama.

c. Keterbukaan pihak pengelola (pengelola day- spa mengizinkan dan membantu peneliti dalam mengumpulkan data terkait day- spa tersebut).

Atas pertimbangan tersebut, maka Ubud Family Reflexology, Zengarden, dan De Spa terpilih sebagai sampel penelitian.

\section{Hasil dan Diskusi}

Berikut merupakan hasil penelitian dari setiap studi lapangan. Dengan pengamatan dari segi fasilitas bangunan, pelayanan yang disediakan, hingga sikap maupun perilaku pengguna terhadap pelayanan dan fasilitas tersebut.

\subsection{Ubud Family Reflexology}

\section{a. Fasilitas}

Bangunan spa yang digunakan adalah rumah toko tunggal, perabot yang digunakan pada spa ini adalah berbahan kayu dengan nuansa nyaman dan diiringi dengan musik juga wewangian ruang beraroma rempah. (Gambar 1). Fasilitas ruang pada bangunan spa Ubud Family Reflexology menggunakan standar ruang menurut Neufert Architects' Data. Namun penyediaan ruang sangat kurang dalam segi jumlah. Fasilitas ruang yang tersedia yaitu ruang tunggu, resepsionis, coffee corner, ruang perawatan, salon, ruang istirahat terapis/pegawai, dan ruang manajer.

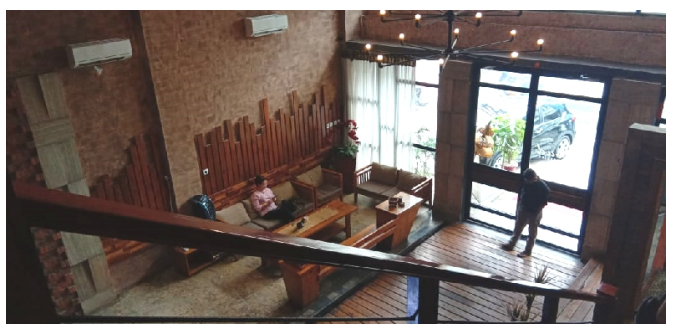

Gambar 1. Layout Lobby Ubud Family Reflexology

(Sumber: Dokumentasi Pribadi, 2019)

Terdapat 9 jenis fasilitas yang sudah sesuai standar dan 31 fasilitas yang belum standar, termasuk 9 ruang yang tersedia dan 22 ruang yang tidak tersedia. Ada beberapa ruang multifungsi, seperti ruang resepsionis dengan ruang kasir dan ruang 
rapat, ruang arsip serta ruang pegawai. Penggabungan beberapa fungsi ruang ini karena sirkulasinya yang sejalan atau berdekatan dan bertujuan untuk mempermudah pengguna dalam menjalankan fungsi ruang. Perbandingan kualitas fasilitas berdasarkan jumlah ruang standar dan tidak standar dapat dilihat pada Gambar 2.

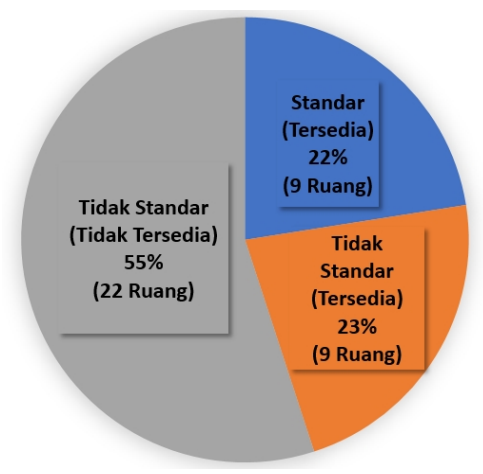

Gambar 2. Diagram Perbandingan Jumlah Fasilitas Ubud Family Reflexology

(Sumber: Dokumentasi Pribadi, 2020)

\section{b. Pelayanan}

Pelayanan spa yang disediakan di Ubud Family Reflexology tergolong minim dari pelayanan spa pada umumnya. Pelayanan yang tersedia hanya berupa pijat badan, pijat kaki dan tangan, dan juga mandi susu. Kegiatan wawancara yang dilakukan terhadap responden acak sebagai sampel dengan 10 orang dihari Senin sampai Jum'at (Weekday) dan 8 orang dihari Sabtu dan Minggu (Weekend), menghasilkan jumlah 464 poin dari poin maksimal yang harusnya diperoleh yaitu 720 poin dengan rata-rata penilaian pelayanan yaitu 3,23. Dan hasil rata-rata tiap indikator, diperoleh dari jumlah penilaian responden dari hari Senin sampai Jum'at (Weekday) dan Sabtu dan Minggu (Weekend) dibagi dengan total jumlah responden yaitu 18 orang. Berikut diagram perbandingan tiap indikator pertanyaan tentang kualitas pelayanan berdasarkan Zulian Yamit (2005). Berdasarkan Gambar 3, pelayanan paling unggul menurut pilihan responden (pengguna jasa spa) yaitu Fasilitas Fisik sebesar 4.22 dari poin rata-rata keseluruhan indikator yang diajukan.

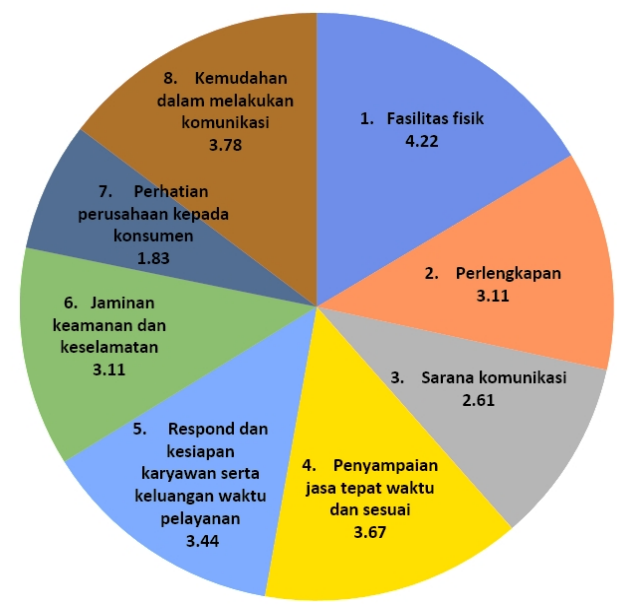

Gambar 3. Diagram Resume Hasil Wawancara Ubud Family Reflexology (Sumber: Dokumentasi Pribadi, 2020) 


\subsection{De Spa}

\section{a. Fasilitas}

Fasilitas ruangan pada De Spa ini sangat bersifat terbuka. Ruangan perawatannya sendiri tidak memiliki sekat sama sekali, hanya menggunakan tirai untuk pemisah dari bed-bed reflexi (Gambar 4.). Pada perawatan sauna, ruangan yang digunakan masih menggunakan ruang perawatan yang sama untuk perawatan pijat badan. Namun yang membedakan, perawatan sauna hanya menggunakan sauna box portable, sehingga ruangan perawatan spa pada bangunan ini tergolong multifungsi.

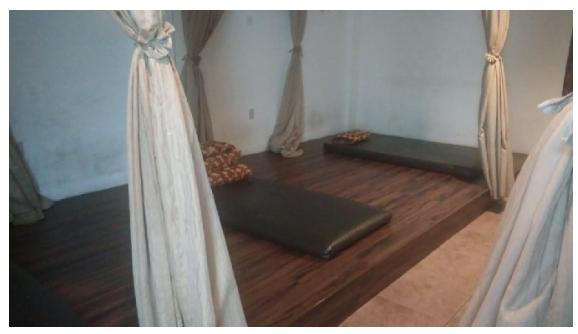

Gambar 4. Ruang Perawatan De Spa

(Sumber: Dokumen Pribadi, 2019)

Berdasarkan hasil survei (2019), jumlah fasilitas yang standar adalah 11 ruang dan 29 jenis ruang belum standar, termasuk 9 ruang yang tersedia dan 20 ruang yang tidak tersedia. Perbandingan kualitas fasilitas berdasarkan jumlah ruang standar dan tidak standar dapat dilihat pada Gambar 5.

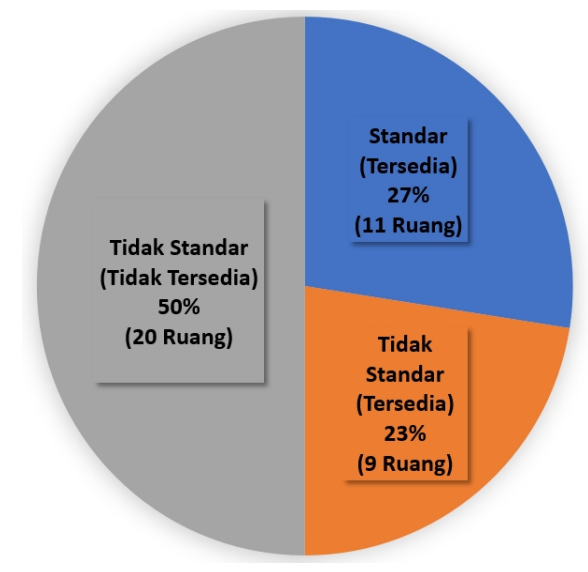

Gambar 5. Diagram Perbandingan Jumlah Fasilitas De Spa (Sumber: Dokumen Pribadi, 2020)

\section{b. Pelayanan}

Pelayanan di De Spa juga masih tergolong sangat kurang dari standar yang ada. Pelayanan yang tersedia yaitu pijat badan, pijat kaki dan tangan, dan sauna. Berdasarkan kegiatan wawancara yang dilakukan terhadap responden acak sebagai sampel dengan 15 orang dihari Senin sampai Jum'at (Weekday) dan 12 orang dihari Sabtu dan Minggu (Weekend), menghasilkan jumlah 719 poin dari poin maksimal yang harusnya diperoleh yaitu 1080 poin dengan rata-rata penilaian pelayanan yaitu 3,33. Dan hasil rata-rata tiap indikator, diperoleh dari jumlah penilaian responden dari hari Senin sampai Jum'at (Weekday) dan Sabtu dan Minggu (Weekend) dibagi dengan total jumlah responden 
yaitu 27 orang. Berikut diagram perbandingan tiap indikator pertanyaan tentang kualitas pelayanan berdasarkan Zulian Yamit (2005). Berdasarkan Gambar 6, indikator pelayanan yang paling unggul menurut pilihan responden (pengguna jasa spa) yaitu dengan poin rata-rata sebesar 3.67 adalah indikator perhatian perusahaan kepada konsumen.

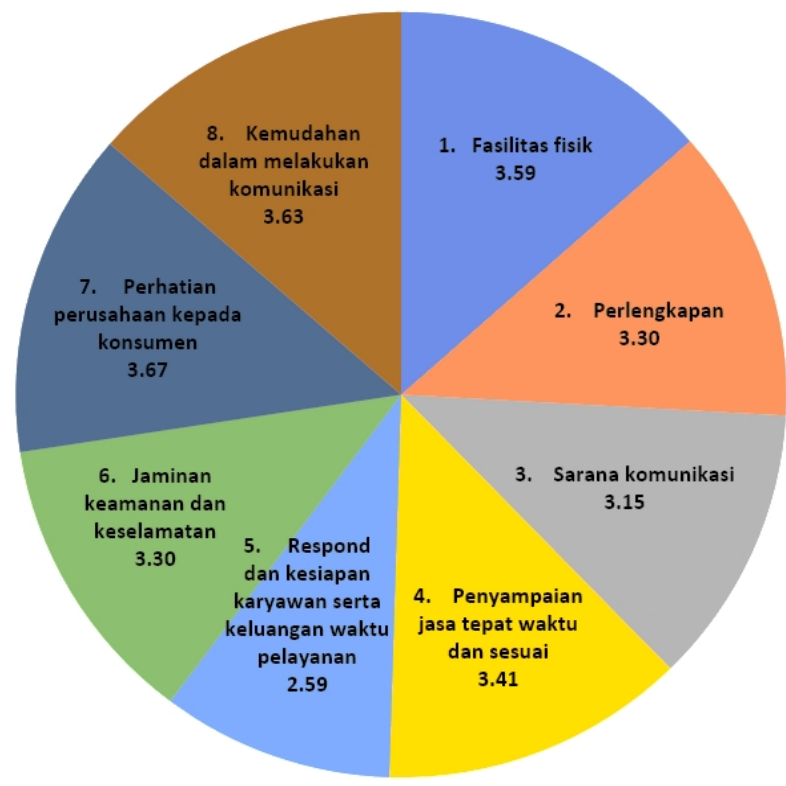

Gambar 6. Diagram Resume Hasil Wawancara Zengarden

(Sumber: Dokumen Pribadi, 2020)

\subsection{Zengarden}

\section{a. Fasilitas}

Bangunan ini memiliki fasilitas ruang yang sudah sesuai dengan standar perancangan spa menurut Neufert Architects' Data. Keseluruhan ruangan yang dimiliki adalah 29 ruangan yaitu resepsionis, ruang tunggu, ruang perawatan, dan kamar mandi. Pada ruang perawatan terdapat pembatas bed berupa dinding dan juga tirai, sehingga privasi pengguna dapat terjaga. (Gambar 7)

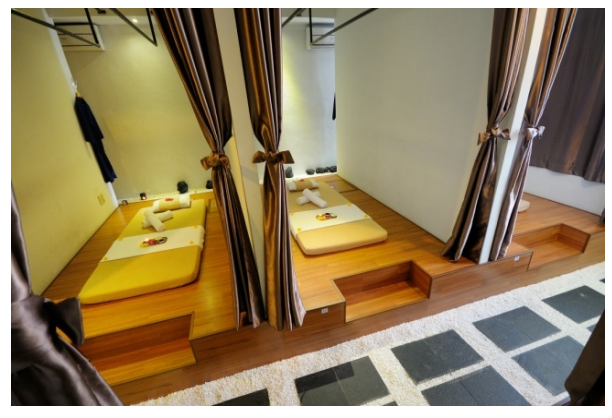

Gambar 7. Ruang Perawatan De Spa

(Sumber: Dokumen Pribadi, 2019)

Berdasarkan survei (2019), fasilitas ruang yang standar berjumlah 15 ruang dan 25 jenis ruang yang belum standar, termasuk 14 ruang yang tersedia dan 11 ruang yang 
tidak tersedia. Perbandingan kualitas fasilitas berdasarkan jumlah ruang standar dan tidak standar dilihat pada Gambar 8.

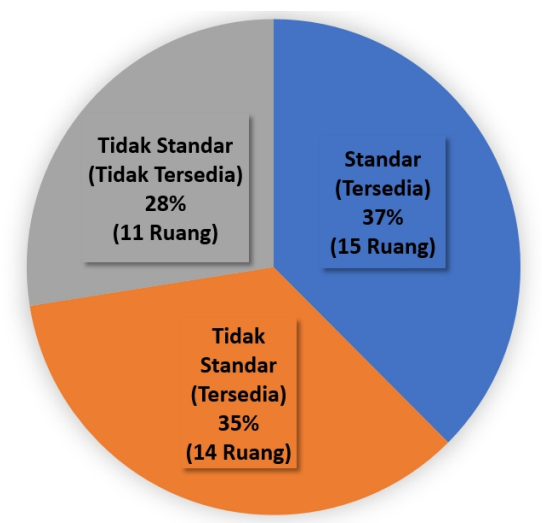

Gambar 8. Diagram Perbandingan Jumlah Fasilitas Zengarden (Sumber: Dokumen Pribadi, 2020)

\section{b. Pelayanan}

Zengarden memiliki pelayanan spa pada umumnya, seperti signature treatment, body treatment, waxing threatment, dan juga IPL hair removal. Berdasarkan kegiatan wawancara dilakukan terhadap responden acak sebagai sampel dengan 22 orang dihari Senin sampai Jum'at (Weekday) dan 18 orang dihari Sabtu dan Minggu (Weekend), menghasilkan 1274 poin dari poin maksimal yang harusnya diperoleh yaitu 1600 poin dengan rata-rata penilaian pelayanan yaitu 3,98. Dan hasil rata-rata tiap indikator, diperoleh dari jumlah penilaian responden dari hari Senin sampai Jum'at (Weekday) dan Sabtu dan Minggu (Weekend) dibagi dengan total jumlah responden yaitu 40 orang. Berikut diagram perbandingan tiap indikator pertanyaan tentang kualitas pelayanan berdasarkan Zulian Yamit (2005).

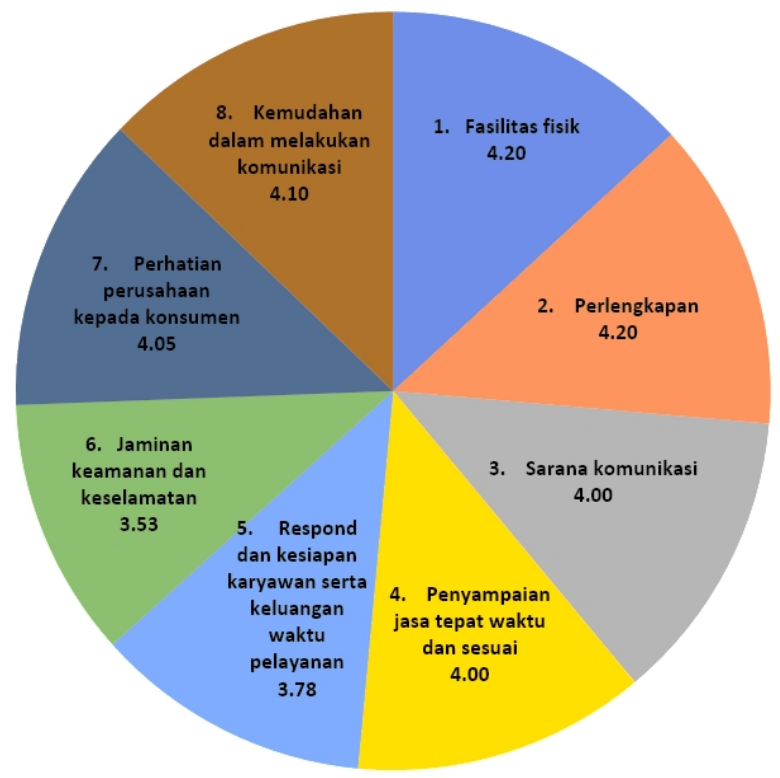

Gambar 9. Diagram Resume Hasil Wawancara Zengarden (Sumber: Dokumen Pribadi, 2020) 
Berdasarkan Gambar 9, indikator pelayanan yang paling unggul menurut pilihan responden (pengguna jasa spa) yaitu dengan poin rata-rata sebesar 4.20 meliputi indikator Fasilitas fisik dan Perlengkapan. Dari ketiga studi kasus yang telah dianalisa, ditemukan bahwa fasilitas dan pelayanan yang tersedia masih kurang dari standar perancangan spa. Dari segi fasilitas, ruang yang standar adalah ruang yang tersedia di day-spa sesuai dengan besaran ruang yang terstandar dari Neufert Architects Data. Sedangkan ruang yang tidak standar adalah ruang yang tersedia di day-spa namun tidak sesuai dengan besaran ruang yang terstandar dari Neufert Architects Data dan ruang yang tidak tersedia di day-spa tersebut.

Menurut PermenParekraf No. 24 Tahun 2014, bahwa Spa Tirta 1 harus memenuhi 40 fasilitas ruang. Studi banding yang dilakukan pada 3 day- spa, memunculkan data bahwa fasilitas yang dimiliki Zengarden yaitu 29 jenis fasilitas dengan 15 ruang yang sesuai standar, 14 ruang yang tidak sesuai standar, dan 11 ruang yang tidak tersedia, De Spa memiliki 20 jenis fasilitas dengan 11 ruang yang sudah memenuhi standar, 9 ruang yang tidak memenuhi standar, dan 20 ruang yang tidak tersedia, dan Ubud Family Reflexology yang memiliki 18 jenis fasilitas dengan 9 ruang sudah memenuhi standar, 9 ruang tidak memenuhi standar, dan 22 ruang yang tidak tersedia. Berdasarkan wawancara terhadap pengguna day-spa di 3 studi kasus yang telah dianalisis, didapatkan hasil kualitas pelayanan dengan peringkat sebagai berikut Zengarden dengan rata-rata penilaian 3,98, De Spa rata-rata penilaian 3,33, dan Ubud Family Reflexology dengan rata-rata 3,23.

\section{Simpulan}

Ubud Family Reflexology, De Spa, dan Zengarden merupakan day- spa dengan kategori Spa Tirta-1 sesuai dengan Peraturan Menteri Kesehatan Republik Indonesia Nomor 8 Tahun 2014 Tentang Pelayanan Kesehatan Spa, karena menyelenggarakan perawatan spa untuk menghasilkan manfaat relaksasi seperti peregangan otot, pijat badan, dan pijat kaki dan tangan untuk mendapatkan kebugaran tubuh kembali. Pemenuhan kualitas pelayanan dan fasilitas day-spa pada penelitian ini ditentukan melalui kategori pelayanan dengan metode wawancara, dan kebutuhan ruang yang sesuai dengan Peraturan Menteri Pariwisata dan Ekonomi Kreatif Republik Indonesia Nomor 24 Tahun 2014 tentang Standar Usaha Spa, dalam hal ini menggunakan Standar Usaha Spa Tirta-1 dengan besaran ruang yang beracuan pada Neufert Architects' Data.

Berdasarkan analisis penilaian responden terhadap kualitas pelayanan yang dilakukan dengan metode wawancara, hasil penelitian mengatakan bahwa rata-rata penilaian yang didapat dengan urutan rata-rata poin tertinggi ke tingkat terendah yaitu : 1) Zengarden (3,98 poin); 2) De Spa (3,33 poin); dan 3) Ubud Family Reflexology (3,23 poin. Pada Ubud Family Reflexology, pelayanan yang tersedia sangat minim, sedangkan pada De Spa dan Zengarden memiliki pelayanan yang cukup banyak namun belum memenuhi kriteria day-spa, menurut Peraturan Menteri Pariwisata dan Ekonomi Kreatif Republik Indonesia Nomor 24 Tahun 2014. Perbandingan tiap indikator kualitas pelayanan antara Ubud Family Reflexology, De Spa, dan Zengarden.

Kualitas fasilitas pada Ubud Family Reflexology, De Spa, dan Zengarden yang dianalisis dengan acuan Peraturan Menteri Pariwisata dan Ekonomi Kreatif Republik Indonesia Nomor 24 Tahun 2014 dan Neufert Architects' Data, adalah kurang memenuhi, fasilitas yang disediakan dengan rata-rata parkir yang ada lebih kecil daripada jumlah pengunjung. Selain tempat parkir, jumlah fasilitas pada ketiga obyek penelitian berbeda, yaitu : 1) Zengarden memiliki 15 ruang yang sesuai standar; 2) De 
Spa memiliki 11 ruang yang sudah memenuhi standar; dan 3) Ubud Family Reflexology memiliki 9 ruang yang sudah sesuai standar.

Hasil penelitian berdasarkan Peraturan Menteri Pariwisata dan Ekonomi Kreatif Nomor 24 Tahun 2014, Peraturan Menteri Kesehatan Republik Indonesia Nomor 8 Tahun 2014 dan Neufert Architects Data, serta hasil wawancara dan observasi yang dilakukan, pelayanan dan fasilitas di Zengarden lebih unggul dari kedua studi kasus lainnya yaitu De Spa dan Ubud Family Reflexology. Penelitian ini berhubungan dengan jurnal-jurnal terkait yaitu Penelitian Hubungan Warna dengan Tingkat Stres Pengunjung (Zein dkk, 2013), Penelitian Persepsi Masyarakat Surabaya Terhadap Spa Sebagai Sarana Perawatan Kesehatan, Kebugaran, dan Kecantikan (Pasla dan Dinata, 2004), dan Penelitian Strategi Pengembangan Health And Wellness di Bali (Pramono, 2013) bahwa penelitian-penelitian ini memiliki kesamaan tujuan dalam mementingkan kualitas pada spa baik dalam pelayanan, fasilitas, desain interior, maupun persepsi pengunjung.

\section{Daftar Pustaka}

ArchDaily, 2015. Hedon Spa /Allianss Arhiketid Ö̈. https://www.archdaily.com/590470/hedo-spa-allianss-arhitektid-ou/, diakses 1 Maret 2019.

ArchDaily, 2015. Naman Spa / MIA Design Studio. https://www.archdaily.com/770560/naman-spa-mia-design-studio/, diakses 1 Maret 2019.

ArchDaily, 2010. Storm Spa Nordique / Chevalier Morales Architectes. https://www.archdaily.com/73063/storm-spa-nordique-chevalier-moralesarchitectes/, diakses 1 Maret 2019.

Pramono, Jaya. 2013. Strategi Pengembangan Health dan Wellness di Bali, Jurnal Manajemen, Strategi, Bisnis dan Kewirausahaan. Volume 7, Nomor 1, hal. 66 - 74.

Kemenparekraf, 2014. Peraturan Menteri Pariwisata dan Ekonomi Kreatif Republik Indonesia Nomor 24 Tahun 2014, Tentang Standar Usaha Spa. http://www.id.scribd.com/doc/238210332/Lampiran-Permen-Nomor-24Tahun-2014-Tentang-Standar-Usaha-Spa.

Neufert, Ernest. Data Arsitek Edisi 33 Jilid 2. Jakarta: Erlangga, 2002.

Pasla, Peter R.Y, dan Dessy I.S. Dinata, 2004. Persepsi Masyarakat Terhadap Spa Sebagai Sarana Perawatan, Kebugaran dan Kecantikan, Jurnal Manaemen dan Kewirausahaan. Volume 6, Nomor 1, Maret 2004, hal. 82 - 92.

Permenkes, 2004. Peraturan Menteri Kesehatan Nomor 1205/X Tahun 2004, Tentang Pedoman Persyaratan Kesehatan Pelayanan Sehat Pakai Air (SPA). http://www.id.scribd.com/doc/93435453/Permenkes-1205-2004-Syarat-SehatAir.

Yamit, Zulian. 2005. Manajemen Kualitas Produk dan Jasa. Edisi Pertama. Yogyakarta: Penerbit Ekonisia Kampus Fakultas Ekonomi UII Yogyakarta.

Zein Anastasha O., dan Tamara Khaerunnisa 2013. Hubungan Warna dengan Tingkat Stres Pengunjung, Jurnal Rekajiva. Volume 1, Nomor 1, hal 1 - 9. 